\title{
Accumulation by Any Means: Neoliberalisation and Environment in Post-Communist Europe ${ }^{1}$
}

\author{
Frederick Peters
}

\begin{abstract}
This paper explores water services restructuring in the post-communist Europe. The cases of the cities of St Petersburg, Russia and Tallinn, Estonia serve to trace changes in tone and timbre over the course of the post-communist transition to a market based economy. This paper is divided into two sections: we begin by placing the European Bank of Reconstruction and Development (EBRD) in the context of the World Bank and International Monetary Fund-the International Financial Institutions significantly involved with infrastructure rebuilding. Section Two presents a brief look at specific cases of municipal water restructuring in the Baltic Region in postcommunist transition period, 1991 - 2006, brokered and funded in part by EBRD money. Tracing investments and the strategic partnerships formed in the region by the EBRD sheds light onto the development of IFI capacity and strategy since the early 1990s. The politics behind the notion described in shorthand with Harvey's reworking of the Marxian 'Primitive Accumulation' is crucial to understanding the dynamics and trends often apparent in water infrastructure restructuring.

Keywords: European Bank of Reconstruction and Development (EBRD), International Monetary Fund (IMF), World Bank (WB), International Financial Institutions ,St Petersburg, Russia, Tallinn, Estonia, Baltic, International Financial Institutions, water, privatization, ownership, post-communist transition, environment.

\footnotetext{
${ }^{1}$ Special thanks go out to the organizers of the Young Researchers Network Transatlantic conference in Florence, April 27th, 2007, Joan DeBardeleben, Kurt Hübner, Beate Schmidtke, Oliver Schmidtke, Bartholomew Paudyn, and the participants for the opportunities to begin, present, and refine this paper as well as the anonymous reviewer(s) for their invaluable critique to help improve it. Further thanks go out to Julia Lajus of the European University in St Petersburg and the participants of a special seminar held there September 24, 2007 for their help in understanding contemporary St Petersburg and Russia. All errors and omissions are of course my own.
} 


\section{Introduction}

This paper explores water services restructuring in post-communist Europe. The cases of the cities of St Petersburg, Russia and Tallinn, Estonia, serve to trace changes in tone and timbre over the course of the post-communist transition to a market based economy. In the initial years of the transition, 1989 to the mid 1990s, between the World Bank, the IMF and economists such as Jeffrey Sachs, a rapid liberalization of all aspects of the economy, Shock Therapy, was the dominant approach to post-communist ownership reforms led by the World Bank (WB) and International Monetary Fund (IMF). But the practice as it has been carried out by recently significant players (since the mid to late 1990s) such as the European Bank of Reconstruction and Development (EBRD) show the stakes to have been a question of public and private responsibility and risk. Very recently (so from 2005 where oil sold for over US\$60 per barrel with trends upwards since ${ }^{2}$ ) soaring oil and gas prices have once more completely altered the relationship between international financial institutions (IFIs) and the Russian Federation. While the two cases share common characteristics up until the early $21^{\text {st }}$ century, in the last few years, the terms have changed. Tracing investments and the strategic partnerships formed in the region by the EBRD sheds light onto the development of IFI capacity and strategy since the early 1990s. As the region develops and changes, with uneven environmental improvements and uneven increases in social welfare and equity, questions of institutional change and arrangements in both the region and among the investors' strategy are evident, but have they been effective and in what way?

This paper is divided into two sections: I begin by placing the EBRD in the context of the World Bank and International Monetary Fund - the international financial institutions 
significantly involved with infrastructure rebuilding. While it has been less the focus of scholarly interest than the other IFIs, my emphasis on the EBRD comes from its status, and its own claims to be the largest single investor in the region's infrastructure. While the WB and IMF can be said to have set the tone for reform and restructuring the region in a mode of 'triumphant capitalism' after the fall of Communism, the EBRD has devoted considerable resources, management and monitoring capacity to trying to make out of restructuring, functional water supply systems. In these as in other specific projects, the EBRD has been specifically and operationally involved.

It is this more intimate involvement with specific projects that makes a study of the EBRD's work revealing of the dynamics of changes in ownership and control of key municipal or local level services. Section two presents a brief look at specific cases of municipal water restructuring in the Baltic region in post-communist transition period (1991-2006) brokered and funded in part by EBRD money. I seek to show changes in approaches to the transition by local and international actors and bring up questions of the social and ecological implications of water valorization in the context of urban water services. Some of the implications for the study of institutions and neoliberal reform as it pertains to environmental change are presented in the conclusion to this paper, where I set out a research agenda for the analysis of the interconnections between macro level changes in the global economy and micro level shifts in the approaches to supplying human basic needs such as water in an urban context. Neoliberalism, a critic's word, not a banker's, is not a stable set of precepts or a coherent ideology. Looking at what has been done in the trajectory of reform in the region allows for some brass tacks conclusions about what has been at stake for the cities, citizens and environment in the region.

\footnotetext{
${ }^{2}$ http://news.bbc.co.uk/1/hi/business/7048600.stm (accessed November 14, 2007).
} 
This paper's title recalls David Harvey's thesis of 'accumulation by dispossession, ${ }^{3}$ but the argument I am constructing is wary of a common anti-privatization presumption that a vague sort of happy collective ownership structure is being replaced by a clearly corporate privatization scheme. Privatization of a common or shared resource amounts to the imposition of a liberal creed of private property rights over a non-liberal logic of collectivity with water infrastructure. In fact and deed, the issue of ownership in the region's water infrastructure is quite complex with pre- and post-communist examples of public and private holdings, better situated along a continuum, and a series of contractual relationships between state and construction, engineering and management firms, either state owned, separate, or in between. Ownership issues and the actual dynamics of post-socialist reorganization of rights of property are simply more complicated than praise for, or criticism of, 'privatization' can address: "Privatization = Divestment of government ownership' is not a sound conceptual formulation of the process; privatization is not the same thing as destatification." Post-communist legal reform in Estonia and Russia transferred water infrastructure responsibility to other local levels of government from the central state, with insufficient support to handle necessary improvements without outside investment. This investment from the EBRD among others was coupled with conditions, including private sector involvement. This remains the case in Tallinn, but is no longer quite so clear in St Petersburg. Oil and gas revenue makes Moscow the financial centre for St. Petersburg, as it were, with the central state in Russia brokering St. Petersburg's infrastructure investment. The local water company has gone corporate but 'public' - i.e., belonging to the region of St Petersburg, which, however is not 'democratically legitimated' as it has a Moscow

\footnotetext{
${ }^{3}$ David Harvey, The New Imperialism (Oxford University Press, 2003).
} 
appointed governor - now after years of EBRD reliance, in what some are calling "outright renationalization."5

The politics behind the notion described in shorthand with Harvey's reworking of the Marxian 'Primitive Accumulation' is crucial to understanding the dynamics and trends often apparent in water infrastructure restructuring. What is important to pursue further is the notion of choice and outcomes: what choices were available to whom (municipalities, regions, corporations, "the people"?) regarding infrastructure investment needs? What have been the ensuing actual environmental and social outcomes? Who has profited, and by whom?

\section{The EBRD, the other IFIs and Baltic Region Water Infrastructure}

Several Central European, as well as the Baltic countries, were affected after WWII by the highly centralised Soviet tradition of state water management. It will be interesting to see to what extent they will "go back" to the municipal tradition, or whether they will choose the private company tradition for the short or long term (Juuti and Katko, 2005: 11).

There has been significant mobilization of financial resources and environmental experts for a 'clean-up' of the Baltic since the early 1990s. To a significant extent, scholarly focus has been less on The European Commission, its own financial tools including the European Investment Bank (EIB) or even the European Bank for Reconstruction and Development despite this latter organization being set up precisely for the purpose of environment and infrastructure rebuilding in the Post-communist world. The World Bank, and the International Monetary Fund

\footnotetext{
${ }^{4}$ Peter Marcuse, "Privatization and its Discontents: Property Rights in Land and Housing in the Transitions in Eastern Europe," in In Andrusz, G, Michael Harloe and Ivan Szelenyi (eds) Cities After Socialism: Urban and Regional Changes in Post-Socialist Societies, (Oxford: Blackwell Publishers, 1996), 119..

5 Anders Aslund, "Focus on Gazprom, Not Sovereign Wealth Funds," St Petersburg Times, Nov 13, 2007, http://www.sptimes.ru/index.php?action_id=2\&story_id=23621 (accessed November 14, 2007).
} 
have instead been the focus of much analysis that tends towards a top down understanding of these organizations, their influence, and the outcomes of their initial responses to the Postcommunist transition.

Certainly the WB and IMF have all been significantly involved in the early transition years and influential in setting a certain tone in Western response to those developments. ${ }^{6}$ Critiques come internally as well, as Gianni Zanini, reporting for the World Bank on the outcomes of its loan commitments in his 2002 Country Assistance Evaluation for the World Bank Operations Evaluation Department, has pointed out. The pressure placed upon Russia for rapid privatization by these institutions did not lead to the expected outcomes of efficiency and stability, despite the large figures reported (US\$ 4.6 Billion in loan commitments between 1992 and 1995). More than half of the projects were said to have suffered "serious implementation problems," which required "intensified supervision" and restructuring. ${ }^{7}$ Woods go so far as to suggest that mid 1990s WB and IMF assistance to the new Russia was politically rather than financially motivated: "major shareholder governments decided that political exigencies overrode technical qualifications" in support of Yeltsin's government against both Communist and nationalist opposition. ${ }^{8}$

These analyses are general and cross many sectors. As relates to the water sector, Allouche and Finger, elsewhere, explain the conflict between World Bank water resources

\footnotetext{
${ }^{6}$ Jeremy Allouche and Matthias Finger, Water Privatisation: Trans-national Corporations And The Re-regulation Of The Water Industry (London: Spon Press, 2002); Ngaire Woods, The Globalizers: The IMF, The World Bank and their Borrowers (Ithaca: Cornell University Press, 2006).

${ }^{7}$ Quoted in a summary of an event sponsored by the Carnegie Foundation where Zanini presented his finding for the World Bank, Thursday, September 12, 2002, "What the World Bank Has Done for Russia: An Evaluation" still available at http://www.carnegieendowment.org/events/index.cfm?fa=eventDetail\&id=516\&\&prog=zru (accessed September 6, 2007). The original report was not found on line by the author.

${ }^{8}$ Woods, Ngaire. The Globalizers: The IMF, The World Bank and Their Borrowers. Ithaca: Cornell University Press, 2006, p. 134.
} 
management policy guidelines and financial restructuring guidelines overall. They suggest that within the WB a "serious simplification" of its own policy guidelines occurred where decentralization of control of water resources came to mean straightforward privatization. ${ }^{9}$ The principles set out at the 1992 UN Conference on Environment and Development at Rio de Janeiro, also known as the Earth Summit, and in the 1992 International Conference on Water and the Environment, known as the Dublin Conference, include integrating environment, user participation, and policy integration at all government and planning levels. Further principles agreed upon at these conferences to guide international planning and World Bank policy state that while water is to be seen as an economic good in all its competing uses (from agriculture and industry to domestic supply), clean water and sanitation are to be guarded as a basic right for all human beings to access at an affordable price. The simplification that seemed to guide the Bank's own guidelines became the equation of these concepts of decentralization and user participation with privatization. Privatization was seen as the answer to the new focus on environmental concerns. The guidelines developed at Rio and Dublin have an international focus and were formulated with the Developing World in mind as much as anywhere. While initial sums of money were committed by the WB and IMF to Russia and post-communist Europe, under conflicting mandates and with controversial results, the European Investment Bank and especially the EBRD have been significantly involved from the early 1990s specifically in this region in this sector.

Established in 1991 with initial investments made by the EIB, the US, France, Germany, as well as other nations in Europe, and including Canada, the EBRD is a compromise and a

\footnotetext{
${ }^{9}$ Jeremy Allouche and Matthias Finger, "Two Ways of Reasoning, One Outcome: The World Bank's Evolving Philosophy in Establishing a "Sustainable Water Resources Management" Policy," Global Environmental Politics 1, No. 2 (May 2001): 42-47.
} 
reflection of a complex of state and market interplay among the leading capitalist nations. It is not an institution of the European Union. As an investment institution it is typical in that it uses this initial capital (public money) to borrow on the market with its top market credit ratings. Capitalized at $€ 20$ billion ( $€ 5$ billion paid-in and $€ 15$ billion callable) and with investments in September 2006 of approximately $€ 2.568$ billion, the EBRD has in 2005 managed to achieve a profit on its investment totalling $€ 1.5$ Billion, up from $€ 157$ Million in $2001 .{ }^{10}$ EBRD.COM makes claims of the Bank being the biggest single investor in infrastructure improvement in Central and Eastern Europe.

Essentially the EBRD was set up with the specific mandate to invest in post-communist Europe and Asia, expressly to foster a nascent private sector and address environmental issues. There are important parallels in its constitution to the Bretton Woods institutions of the WB and IMF established to rebuild Europe at the end of the Second World War, but also differences, specifically regarding its purported agenda. Its mandate around environmental issues and the promotion of democracy are of course worthy ambitions. Investigation reveals ambivalent outcomes.

The EBRD shares with the EIB and others an environmental mandate, but each has come to focus on environment for different reasons. The EIB was established as an institution of the Union with the Treaty of Rome, 1957, as the (then) European Economic Community's financing institution. Currently it bills itself as "the Bank promoting European objectives" objectives include European integration through energy, water and transport infrastructure, and balanced economic development for social cohesion of Member States, making it not an investment bank per se, but a strategic arm of European Commission policy both inside and

\footnotetext{
${ }^{10}$ See www.ebrd.com and specifically http://www.ebrd.com/pubs/general/6710.pdf (accessed March 21, 2007).
} 
outside the Union. The EIB has similar profit results from its investments as the EBRD ( $€$ 1, 389 Million in 2005). ${ }^{12}$ The environmental mandate in its objectives is to promote "the environmental policy of the European Union, in particular the EU's Sixth Environment Action Programme. ${ }^{13}$ This programme dovetails with the Water Framework Directive (WFD). The WFD, an overarching piece of EC legislation that summarizes the myriad of previous water related law in the EU with some important new guidelines around pollution toleration levels and implementation timelines for new member states of the EU, has come to frame and drive infrastructure improvement in the sorts of investments made by the EBRD since it came into force on 22 December $2000 .{ }^{14}$ One cannot say that the WFD, or the previous pieces of legislation it contains, are driving privatization per se, as that pressure is better linked to the financial institutions themselves. What the WFD does do is add to the pressure to seek further financing for infrastructure rebuilding through corporate involvement in order for water supply and treatment facilities to adhere to EU standards, required by all member states. It does remain in part the polluting substances that have spawned the pressure to restructure and reform water services. $^{15}$

${ }^{11} \mathrm{http}: / /$ www.eib.org/ (accessed November 14, 2007).

${ }_{12}^{12} \mathrm{http://www.eib.org/about/index.asp?designation=keydata} \mathrm{(accessed} \mathrm{March} \mathrm{21,} \mathrm{2007).}$

${ }^{13}$ http://www.eib.org/site/index.asp?designation=environmen,t (accessed March 21, 2007). For the EU's $6^{\text {th }}$ Environmental Action Programme see http://ec.europa.eu/environment/newprg/. The $6^{\text {th }}$ Environmental Action Programme is more of a list of priorities developed since the First EAP developed after 1972 UN Conference on the Environment in Stockholm by the then European Community. EIB financing of "environment and urban infrastructure" includes city water supplies and treatment such as $€ 15$ million (of a total project of $€ 70$ million) proposed in 2002 for Kaliningrad and Baltic Clean Up in cooperation with the Nordic Investment Bank and EBRD. ${ }^{13}$ This scale of investment is fairly typical of the size of projects each of these organizations has been pursuing.

${ }^{14}$ The UK Government's Department of Agricultural and Rural Affairs provides an outstanding on-line summary and series of PDFs around the WFD, at http://www.defra.gov.uk/environment/water/wfd/index.htm (accessed November 14, 2007).

${ }^{15}$ Maria Kaika and Ben Page, "The EU Water Framework Directive: Part 1. European Policy: Making and the Changing Topography of Lobbying," European Environment 13 (2003): 314-327. European and then national rules (required to 'harmonize' with EC directives) are specific about organic and inorganic compounds in water systems through such legislation, a document that both summarizes earlier directives and is itself codification of the 
The distinctions between these organizations are clear, but how they effectively function remains murky. Their cooperation and the penetration of the EBRD by the EIB as well as member nations from Europe and the US and Canada require more study and analysis as part of a systematic research agenda. How and by whom are decisions about cooperation and investment partnerships made when both public and supposedly democratically controlled funds are mixed with private sector holdings such as the market support called upon by the EBRD when it makes its loans? What is more, as the EBRD financing has at its source a series of national commitments underwriting its investments, how are we to understand the balance of public and private?

What these organizations are doing is offering the sums they do to then foster private investment amongst other things from corporate water giants developing their holdings in the region. As the Public Services International Research Unit (PSIRU) reports, one of the top four water companies [Veolia Environnement (until 2003 called Vivendi), Suez (Ondeo), RWE (Themes Water) and Bouygues (SAUR)] is involved in nearly every urban water privatization scheme in the world. ${ }^{16}$ Veolia Environnement (VE), part owners with RWE and the Land of Berlin of Berlinwasser AG and Istanbul's water services, as well as Prague's water company in partnership with Anglican water group, has recently announced a contract signed with St Petersburg's Vodokanal to help build a sludge treatment plant for the North St. Petersburg wastewater treatment plant. Revenue for VE for the contract is $€ 52$ million out of a total of $€ 70$ million for the entire project. ${ }^{17}$ The EBRD retains a strong interest in investment in the North

negotiations carried out at the European Commission and European Parliament, under lobby pressure from forces from both environmentalists and water treatment chemical industries

${ }^{16}$ Cited in Erik Swyngedouw, "Water, Money and Power," in Socialist Register 2007, eds. L. Panitch and C. Leys (London: Merlin, 2007), 204.

${ }^{17}$ http://www.veoliawater.com/access/press/?news=704 (accessed November 14, 2007). 
West of Russia, including Vodokanal, as recent comments in the St Petersburg Times by Bruno Balvanera, head of the North West Federal District office of the EBRD show. ${ }^{18}$ European based capital (with unclear US financial and US national involvement) has organized an interesting interaction between public and private sector holdings and control of key resources in this mix of money and water that is the water services restructuring process of the post-communist transition. But, as the Russian Federation becomes increasingly liquid with oil revenue and with the ambitious Felix Karmazinov, winner of the 2005 Swedish Baltic Sea Award ${ }^{19}$ and the title of Commander of the Order of the Finnish Lion, "in recognition of his long-standing work for the protection of the Gulf of Finland, in cooperation with Finnish enterprises" ${ }^{20}$ as General Director of the State Unitary Enterprise Vodokanal of St Petersburg, there is increasingly less reason for Russia or St Petersburg to behave as if it is in need of this international investment. Neither is it necessary for Russia to put up with the 'conditionality' of IFI loans, or feel it requires the cooperation of international (non-Russian) corporate involvement.

\section{Two Cities and their Water Services}

Details of ownership restructuring and the conditions of investment in the urban centres of the Baltic open up questions about the way the post-communist transition has been handled and how certain actors have benefited over others. Looking at cases in greater detail problematizes the notion that market reform leads to democratic institution building. But even

\footnotetext{
${ }^{18}$ http://www.sptimes.ru/index.php?action_id=2\&story id=22198 (accessed November 14, 2007).

${ }_{19}$ Cf: http://www.siwi.org/sbswa/sbswalaureate2005.html (accessed November 14, 2007).

${ }^{20}$ Vladimir Kovalev “City Plans to Stop Polluting Baltic” St Petersburg Times, 9/6/2004, available at http://cache.zoominfo.com/CachedPage/?archive_id=0\&page_id=814566496\&page_url=\%2f\%2fwww.times.spb.ru $\% 2$ farchive $\% 2 \mathrm{ftimes} \% 2 \mathrm{f} 1001 \% 2 \mathrm{fnews} \% 2 \mathrm{fn} \_13462 . \mathrm{htm} \&$ page_last_updated $=9 \% 2 \mathrm{f} 6 \% 2 \mathrm{f} 2004+10 \% 3 \mathrm{a} 15 \% 3 \mathrm{a} 30+\mathrm{P}$ $\underline{M} \&$ firstName$=$ Felix \&lastName=Karmazinov (accessed November 14, 2007).
} 
'good governance' notions supported later in the transition process ${ }^{21}$ are coupled with a deficit in democratic local control.

In St Petersburg, VE's recent contract with Vodokanal follows a decade of multi-partner deals: 1990s restructuring made a hybrid of public and public /private arrangement. In the EBRD financing of St. Petersburg's Vodokanal, DM 35 million was loaned initially (€17.5 Million approximately). A 1997 EBRD press release statement about St Petersburg's Vodokanal emphatically supported an ownership structure in municipal control: "Vodokanal's operational performance, the quality of its management and the strong support it has from the City of St. Petersburg allow the EBRD to rely solely on Vodokanal's financial strength to repay the loan."22

Restructuring occurred after 1997. The EBRD reported in 2002: “To complete the South West Waste Water Treatment Plant (SWWWTP) in St. Petersburg to reduce the discharge of untreated waste water in the Gulf of Finland", [...] up to [€] 42 million [...] will be provided to Nordvod with co-financing provided by public and private parties. Nordvod is a limited liability special purpose company registered under Russian law and owned by the Nordic Environment Finance Corporation, Vodokanal of St. Petersburg and a group of Nordic construction companies comprising Skanska AB, NCC AB and YIT Corporations". ${ }^{23}$ Completion of the project in 2005 was announced as the first successful public-private partnership (PPP) in Russia. ${ }^{24}$

Tallinn, Estonia, has lower tiered water companies such as United Utilities in with Bechtel involved in its water services. January 2001, United Utilities was awarded a 15 year

\footnotetext{
${ }^{21}$ Cf European Bank for Reconstruction and Development Transition Reports. (1995-2006) London: EBRD Publications Office.

${ }^{22}$ EBRD Press Release, "St Petersburg improves water supply and waste-water services with EBRD financing", 17 July 1997.

${ }^{23}$ http://www.ebrd.com/projects/psd/psd2002/677stp.htm (accessed Nov. 17, 2003). See also http://ebrd.com/country/sector/muninfra/signed/main.html (accessed Oct. 13, 2003).

${ }^{24}$ http://www.yitgroup.com/Content.aspx?path=16407;16412;30910;31128 (accessed November 14, 2007).
} 
contract to manage water and wastewater services for the Estonian capital, serving over 400,000 people. A "Baltic State Report" by Radio Free Europe online from 2003 notes about the Bank's loans: "The European Bank for Reconstruction and Development will give Tallinna Vesi a €22.5 million (\$22 million) loan, of which $€ 15.5$ million would be used to refinance a 1994 loan. [...The] EBRD will also invest $€ 10$ million in the equity capital of Tallinna Vesi, once the city has sold a 50.4 percent stake to a strategic investor" (emphasis added). ${ }^{25}$ In June 2005, Tallinna Vesi was successfully listed on the Estonia Stock Exchange through an Initial Public Offering (IPO). United Utilities participated in this process by placing part of its total shareholding in the business, reducing their joint stake held with the EBRD to 35.3 per cent. ${ }^{26}$ The City of Tallinn owns $34.7 \%$ and the Nordea Bank (Finland) handles $11 \%$ of the utility. From its initial IPO of $€ 9.25$, the stock is increased to $€ 13.48$ in Dec $2005 .{ }^{27}$ It is worth $€ 16.25$ by March, 2007.

In both St Petersburg and Tallinn, what appeared to be efficiently run utilities owned by the municipalities ${ }^{28}$ (and surplus revenue was circulated back to them) became examples of significant international corporate interest, pushed to be so by various factors, including the conditions of EBRD financing. Critics of privatization posit that these factors do not include simple definitions of efficiency or supposed municipal incompetence but are examples of ideological shifts in the balance of public versus private management and opportunism using public monies to support capitalist intensification at the expense of public benefit. This seems to apply to 'state capitalist' interests equally.

\footnotetext{
${ }^{25}$ http://www.rferl.org/balticreport/2000/08/27-070800.html (accessed Nov. 17, 2003).

${ }^{26}$ See http://www.uucontractsolutions.co.uk/?OBH=3515; http://www.watertime.net/Docs/WP3/WTEC.pdf (accessed November 14, 2007).

${ }^{27} \mathrm{http} / / /$ www.baltic.omxgroup.com/upload/reports/tve/2005_q4_en_eek.pdf (accessed November 14, 2007).

28 http://www.watertime.net/Docs/WP3/WTEC.pdf, p. 58, (accessed November 14, 2007).
} 
These illustrations of the way the transition to market based economies goes brings up questions of social equity and makes problematic the relationship of neoliberal restructuring and democratic institutional ambitions. Debates about the nature of the transition are interesting in so far as the dominant view which comes from the investment institutions themselves in certain cases blithely takes for granted that its approach will result in the realization of its environmental and democratic mandates. Even when the Transition literature admits to governance issues, it still assumes that the capitalist logic of shareholder value increase will somehow result in an increase in liberal democracy and social welfare. Meanwhile, commentators on the Russian situation, with one story running in both the Moscow and St Petersburg Times, quote Financial Times chief economist Martin Wolf, that we are "living in the brave new world of state capitalism. ${ }^{, 29}$ Citing state reserves in the form of Sovereign Funds for monetary stabilization in Russia exceeding $\$ 148$ billion making this the fifth-largest sovereign fund, the newspapers continue: "The countries that were hit by this crisis [of 1998] realized that they could not rely upon the International Monetary Fund as a fire brigade and that they needed to create their own sufficient reserves. It is commendable that the East Asian and former Soviet states have adopted such conservative fiscal policies." What implications this has for the IMF is expressed between the lines with a certain sang froid, although recent comments by Ngaire Woods, ${ }^{30}$ fresh from ministerial-level meetings of the International Monetary and Financial Committee (IMFC), the IMF's policy-guiding body, and the Development Committee, a joint IMF-World Bank forum,

\footnotetext{
${ }^{29}$ Anders Aslund, "Focus on Gazprom, Not Sovereign Wealth Funds," St Petersburg Times, Nov 13, 2007, http://www.sptimes.ru/index.php?action_id=2\&story_id=23621. In the Moscow Times, the same story was published Thursday, November 8, 2007. Available at http://pda.moscowtimes.ru/article.php?aid=180899 . The Financial Times Podcasts, available at http://podcast.ft.com/?section=martinwolf and http://www.podplanet.com/episode detail.asp?eid=1516903 (accessed November 14, 2007).

${ }^{30}$ Ngaire Woods, "Current Revolutions in the World of Development Finance," Friday, October 19, 2007, 4:00 PM 6:00 PM, Political Science Department, University of Toronto. See also World Bank Group International Monetary Fund web site http://www.imf.org/external/am/2007/index.htm, accessed November 14, 2007.
} 
suggest Russia, China and a few other middle sized states have turned their back on the IMF leaving that institutions concerned about its future.

\section{Conclusions}

Corporatization of water utilities in post-communist urban Europe is largely a fait accompli. Ownership has been spread out. Risk has become the issue as risk in these investments rests heavily on the local government side rather than the corporate side. The IFIs had hopes that water privatization would solve problems with water in developing nations, something that has clearly failed. ${ }^{31}$ Central and Eastern European operations are a different sort of story. EU, EBRD, EIC and other influences are certainly part of the explanation. These include cohesion funds, taxation systems, tariff increases, choice urban centres without obligation to service outlying non-urban regions. When you cherry pick concessions, ${ }^{32}$ you are more likely to do well. In the case of Tallinn, profits seem to match increases in tariffs awfully well. Current ownership structuring is leaving the water company of the City of Tallinn reaping 35 per cent of the resident water users own money paid out. On the up side, investment is being realized in increased environmental measures being carried out. In St Petersburg, the jury is still out, but with renationalization and corporatization, very little democratization is occurring. Tallinn is an example of a utility being groomed for increased attractiveness to the private sector, who buys up partial ownership and proceeds to increase tariffs and profits, siphoning money away form municipalities who, had they been able to secure investment themselves could conceivably share the profit around within the city. St Petersburg is turning its back on European capitalism, the

\footnotetext{
${ }^{31}$ David Hall, "EU faith in private water finance shows ignorance," EU Observer, 27.03.2007, http://euobserver.com/875/23785, accessed March 27, 2007
} 
IFIs as well. But this movement is not socially minded. State capitalism run in the name of people it does not represent formally, lacking in democratic institutions to legitimate it, yet running towards profit for the corporation, in an alarmingly successful hybrid of models.

The implications of this surpass the notion of simply dispossessing a group of people from their own life support systems, as they are effectively and sometimes de facto dispossessed. Implications are of the order of the commodification of these life support systems and the rendering democratic decision making around water infrastructure tricky. This stands in contradiction with the mandates of the investment institutions to foster democracy in the 'transition' countries.

Does it matter who owns what now under a corporate logic? The trajectory we have seen is from a privatization drive to a state and institutional capacity building drive. Extra democratic governance and support for capital accumulation accompanies this in the water sector. Other options have become inconceivable, as the only way loans seem to function is by 'fostering' a private sector involvement within these structures of utility ownership. Even where loans come from the state as in Russia, and the Vodokanal is a state unitary enterprise, public ownership is sidestepped. The trend in the Global South has been for big water companies to divest and pull out of contractual obligations ${ }^{33}$ while in the post-communist region we are indeed seeing an intensification of corporate and financial interest, be it French, EU, EBRD or indeed Russian. The Baltic region is one where states, hamstrung by historical circumstances as the transition process develops, are subject to radical transformations from within and without. The upside now, 15 years later, is that EU environmental regulations are closer to being met. The St.

\footnotetext{
${ }^{32}$ Erik Swyngedouw, "Dispossessing H20: the Contested Terrain of Water Privatization," Capitalism Nature Socialism 16 (1) (March 2005).
} 
Petersburg Vodokanal General Manager has made statements that St Petersburg water will be

clean by 2010 as it flows into the Baltic. ${ }^{34}$ Yet currently, although the water is 'clean' by some standards, a boil advisory remains. ${ }^{35}$

\footnotetext{
${ }^{33}$ David Hall, "EU faith in private water finance shows ignorance," EU Observer, 27.03.2007, http://euobserver.com/875/23785 (accessed March 27, 2007).

${ }^{34}$ City Plans to Stop Polluting Baltic" St Petersburg Times, 9/6/2004, available at http://cache.zoominfo.com/CachedPage/?archive id=0\&page id=814566496\&page url=\%2f\%2fwww.times.spb.ru $\% 2$ farchive $\% 2 \mathrm{ftimes} \% 2 \mathrm{f} 1001 \% 2 \mathrm{fnews} \% 2 \mathrm{fn} \_13462$.htm\&page last_updated $=9 \% 2 \mathrm{f} 6 \% 2 \mathrm{f} 2004+10 \% 3 \mathrm{a} 15 \% 3 \mathrm{a} 30+\mathrm{P}$ M\&firstName $=$ Felix\&lastName=Karmazinov (accessed November 14, 2007).

${ }^{35}$ City Tap Water 'Clean Enough to Drink' St Petersburg Times, Issue \#1082 (48), Tuesday, June 28, 2005, http://www.sptimes.ru/index.php?action_id=2\&story_id=69\&highlight=water.
} 


\section{Bibliography}

Allouche, Jeremy, and Matthias Finger. "Two Ways of Reasoning, One Outcome: The World Bank's Evolving Philosophy in Establishing a "Sustainable Water Resources Management" Policy." Global Environmental Politics 1, No. 2 (May 2001): 42-47.

Allouche, Jeremy, and Matthias Finger. Water Privatisation: Trans-national Corporations and The Re-regulation Of The Water Industry. London: Spon Press, 2002.

Anders Aslund, "Focus on Gazprom, Not Sovereign Wealth Funds," St Petersburg Times, Nov 13, 2007 http://www.sptimes.ru/index.php?action_id=2\&story_id=23621 (accessed November 14, 2007).

Bakker, Karen. An Uncooperative Commodity: Privatizing Water in England and Wales. London: Oxford University Press, 2006.

Barnett, C. “The consolation of "neoliberalism.” Geoforum 36 (2005): 7-12.

Blanchard, Olivier. The Economics of Post-Communist Transition. London: Oxford University Press, 1999.

Bronstone, Adam. The European Bank for Reconstruction and Development: The Building of a Bank for East Central Europe. Manchester: Manchester University Press, 1999.

Buiter, Willem H. "From predation to accumulation? The second transition decade in Russia." Economics of Transition 8 (3) (2000): 603-622.

Castree, N. "Commodifying What Nature?" Progress in Human Geography 27, no. 3 (2003): 273-297.

Dejak, Bojan. The Cold War Was Won in the Nineties: Or a Short History of the European Bank for Reconstruction and Development. Victoria: Trafford Publishing, 2006.

Desfor, G and Keil, R. Nature and the City: Making Environmental Policy in Toronto and Los Angeles. Tucson: University of Arizona Press, 2004.

European Bank for Reconstruction and Development. Transition Report 2004: Infrastructure. London: EBRD Publications Office, 2004.

European Environment Agency. "Europe's Water: an indicator-based assessment.” EEA, Copenhagen, 2003, http://www.eea.eu.int.

David Hall, "EU faith in private water finance shows ignorance," EU Observer, 27 March 2007, http://euobserver.com/875/23785, accessed March 27, 2007

Harvey, David. The Limits to Capital. New and fully updated version. London: Verso, 2006.

Harvey, David. The New Imperialism. Oxford University Press, 2003.

Juuti, Petri, and Tapio Katko. "City in Time." Report from Watertime, a research project funded by the European Commission, coordinated by the PSIRU, University of Greenwich, 2005. Available at http://www.watertime.net/wt_reports.asp. 
Kaika, Maria, and Ben Page. "The EU Water Framework Directive: Part 1. European Policy: Making and the Changing Topography of Lobbying." European Environment 13 (2003): 314-327.

Kaika, Maria, and Ben Page. "The EU Water Framework Directive: Part 2. Policy Innovation and the Shifting Choreography of Governance." European Environment 13 (2003): 328-343.

Kaika, Maria. City of Flows: Modernity, Nature and the City. New York: Routledge, 2005.

Keil, Roger, David V.J. Bell, Peter Penz and Leesa Fawcet. Political Ecology, Global and Local. London: Routledge, 1998.

Kovalev, Vladimir "City Plans to Stop Polluting Baltic." St Petersburg Times, 9 June 2004, online at http://cache.zoominfo.com/CachedPage/?archive_id=0\&page_id $=814566496 \&$ page_url $=\% 2 \mathrm{f} \% 2 \mathrm{fwww}$.times.spb.ru\%2farchive $\% 2 \mathrm{ftimes} \% 2 \mathrm{f} 1001 \% 2 \mathrm{fnew}$ s\%2fn_13462.htm\&page_last_updated=9\%2f6\%2f2004+10\%3a15\%3a30+PM\&firstNam $\mathrm{e}=$ Felix \&lastName $=$ Karmazinov (accessed November 14, 2007).

Leys, Colin. Market Driven Politics: Neoliberal Democracy and the Public Interest. London: Verso, 2001.

Lobina, Emanuele. "Water privatisation and restructuring in Central and Eastern Europe, 2001.' Public Services International Research Unit (PSIRU), University of Greenwich. Presented at Public Services International (PSI) seminars in Slovakia and Romania, 2001. Available at http://www.psiru.org (accessed October 10, 2003).

Marcuse, Peter. "Privatization and its Discontents: Property Rights in Land and Housing in the Transitions in Eastern Europe." In Cities After Socialism: Urban and Regional Changes in Post-Socialist Societies, eds. G. Andrusz, Michael Harloe, and Ivan Szelenyi, 119-91. Oxford: Blackwell Publishers, 1996.

Menkveld, Paul A. Origin and Role of the European Bank for Reconstruction and Development. London; Boston: Graham \& Trotman, 1991.

Mohajeri, Shahrooz. "Trinkwasserversorgung und Nutzung im Berlin Des 19.Jahrhunderts.” In Blickwechsel: Beiträge zur Geschichte der Wasserversorgung und Abwasserentsorgung in Berlin und Istanbul, eds. Noyani Dinckal and Shahrooz Mohajeri, 39-58. Berlin: TU Verlag, 2001.

Moharjari, S., Knothe, B., Lamothe, D., Faby, J., (eds). Aqualibrium: European Water Management between Regulation and Competition. European Commission Community Research, Luxembourg, Office for Official Publication of the European Communities, 2003.

Nonaka, I. and Takeuchi, H.. The Knowledge-Creating Company: How Japanese Companies Create the Dynamics Of Innovation. New York; Oxford: Oxford University Press, 1995.

Panitch, L. and S. Gindin. "Finance and American Empire." In Socialist Register 2005, eds. Leo Panitch and Colin Leys. London: Merlin, 2004.

Saad-Filho, Alfredo, and Deborah Johnston, eds. Neoliberalism: A Critical Reader. London: Pluto Press, 2005. 
Sachs, Jeffrey. "What is to be Done?" The Economist, 13 January, 1990.

Spender, J.-C. "Organizational knowledge, learning and memory: three concepts in search of a theory." Journal of Organizational Change Management 9, Is. 1 (1996): 63-72.

Swyngedouw, Erik. "Dispossessing H20: the Contested Terrain of Water Privatization." Capitalism Nature Socialism 16 (1) (March 2005): 81-98.

Swyngedouw, Erik. "Water, Money and Power." In Socialist Register 2007, eds. Leo Panitch and Colin Leys, 195-212. London: Merlin Press, 2007.

Swyngedouw, Erik. Social Power and the Urbanization of Water - Flows of Power. Oxford: Oxford University Press, 2004.

Woods, Ngaire. The Globalizers: The IMF, The World Bank and Their Borrowers. Ithaca: Cornell University Press, 2006.

Zanini, G, "What the World Bank Has Done for Russia: An Evaluation", prepared for the World Bank Operations Evaluation Department (OED).Thursday, September 12, 2002 still available at http://www.carnegieendowment.org/events/index.cfm?fa=eventDetail\&id $=516 \& \&$ prog $=$ zru $($ accessed September 6, 2007). 